\title{
Breakdown of antimicrobial host defense barrier as trigger of chronic inflammatory bowel diseases
}

Jan Wehkamp

From 6th European Workshop on Immune-Mediated Inflammatory Diseases

Nice, France. 23-25 November 2011

Inflammatory bowel diseases are characterized by chronic intestinal inflammation at different sites. Data from animal models as well as human patients including gene-association studies suggest that different components of the innate barrier function are primarily defective. These recent advances support the evolving hypothesis that intestinal bacteria induce inflammation predominantly as a result of a weakened innate mucosal barrier in genetically predisposed individuals. The mechanisms include different defects in epithelial stem cell differentiation, defective pattern recognition, autophagy, endosomal stress and others. Secretory cells like the Paneth cell of the small intestinal crypt as well as mucin producing goblet cells seem to be of major importance in the initial stages of the disease process. This talk will discus our current understanding of the primary events of disease and also outline consequences for future therapeutic consequences. In summary, there is a need for therapeutic avenues aimed at restoring antimicrobial barrier function to prevent a bacterial-triggered inflammatory response.

Submit your next manuscript to BioMed Central and take full advantage of:

- Convenient online submission

- Thorough peer review

- No space constraints or color figure charges

- Immediate publication on acceptance

- Inclusion in PubMed, CAS, Scopus and Google Scholar

- Research which is freely available for redistribution

\section{Biomed Central}

(C) 2011 Wehkamp; licensee BioMed Central Ltd. This is an open access article distributed under the terms of the Creative Commons Attribution License (http://creativecommons.org/licenses/by/2.0), which permits unrestricted use, distribution, and reproduction in any medium, provided the original work is properly cited. 